\title{
Effectiveness of isofetamid, a new succinate dehydrogenase inhibitor fungicide, in the control of grapevine gray mold
}

\author{
Carlos M. Piqueras, Bernardo A. Latorre, and René Torres \\ Facultad de Agronomía e Ingeniería Forestal and Facultad de Ciencias Biológicas, Pontificia Universidad \\ Católica de Chile. Casilla 306-22, Santiago, Chile.
}

\begin{abstract}
C.M. Piqueras, B.A. Latorre, and R. Torres. 2014. Effectiveness of isofetamid, a new succinate dehydrogenase inhibitor fungicide, in the control of grapevine gray mold. Cien. Inv. Agr. 41(3):365-374. Gray mold is an important disease in grapevines in Chile, and its control depends primarily on the use of fungicides with a single-site mode of action. Botrytis cinerea has a high risk of developing resistance against such fungicides. Therefore, novel chemical options are needed to achieve satisfactory control of gray mold. Isofetamid is a new succinate dehydrogenase inhibitor (SDHI) fungicide with a single-site of action that inhibits cellular respiration and appears to be a new option in the chemical treatment against gray mold. The aim of this study was to determine the effectiveness of isofetamid in controlling grapevine gray mold in Chile. Field trials undertaken in three different commercial vineyards showed that isofetamid controls gray mold to a similar extent as fenhexamid. During 2012 and 2013, $10 \mathrm{~B}$. cinerea isolates were obtained from commercial vineyards in central Chile to determine their sensitivity to isofetamid. The median inhibitory concentration of isofetamid varied between $0.3-10.0 \mu \mathrm{g} \mathrm{mL}{ }^{-1}$ and 0.6 to $>10 \mu \mathrm{g} \mathrm{mL}^{-1}$ for mycelium and conidia, respectively. The efficacy of isofetamid against B. cinerea in apple bioassays varied between $61-100 \%$ and $37.5-100 \%$ for mycelium and conidia, respectively. The results of this study demonstrate that isofetamid is a highly effective fungicide against $B$. cinerea.
\end{abstract}

Key words: chemical control, fenhexamid, fungicides, isofetamid, SDHI, Vitis vinifera.

\section{Introduction}

Gray mold, caused by Botrytis cinerea, is the most important disease in table grapes (Vitis vinifera) in Chile and other countries (Bulit and Dubos, 1988; Latorre, 1986). It is a polycyclic disease with abundant inoculum production during spring, summer, and autumn, leading to difficult control. The use of fungicides with a single-site mode of action favors the develop-

Received May 22, 2014. Accepted October 26, 2014. Corresponding author: blatorre@uc.cl ment of resistant strains of $B$. cinerea (Leroux et al., 2007).

Integrated control strategies are suggested for gray mold, and crop cultural practices (e.g., leaf removal, cluster thinning, and vigor management) and chemical control are the most frequent sustainable plant control strategies used by farmers (Broome et al., 1995; Molitor et al., 2011). Chemical control strategies are primarily applied at flowering, beginning of berry touch (prebunch closure) and between veraison and harvest, which are critical grapevine growth periods of gray 
mold infection (Latorre et al., 2001). Several fungicides with different sites of action have been introduced with the aim of controlling gray mold. Some of these fungicides have multiple sites of action (e.g., captan, chlorothalonil), while others have a single-site of action (e.g., boscalid, cyprodinil, fludioxonil, fenhexamid, fluazinam, pyraclostrobin, pyrimethanil) (Chatzidimopoulos et al., 2013; FRAC, 2013).

Currently, chemical control in Chile relies mainly on fungicides with a single-site mode of action (Latorre and Torres, 2012). Consequently, the risk of resistance development is medium to high (FRAC, 2013; Kim et al., 2012), and antiresistance strategies are needed to prevent the rapid appearance of resistant $B$. cinerea strains. These resistance management strategies include limiting the number of applications per growing season, rotation of fungicides with different modes of action, and the use of pre-packed mixtures or tank mixing of fungicides with different modes of action (Forster and Staub, 1996).

Isofetamid is a new fungicide currently under worldwide development and is manufactured by
Sumitomo (Japan). It belongs to the phenyl-oxoethyl thiophene amide chemical group (FRAC, 2013) and has a single-site mode of action that inhibits fungal respiration by blocking electron transport, which is achieved by reducing the activity of the succinate dehydrogenase at complex II in the electron chain in the inner mitochondria membrane (FRAC, 2013). This new fungicide and the more commonly known fungicide boscalid are succinate dehydrogenase inhibitors (SDHIs) (Avenot and Michailides, 2010; FRAC, 2013). The objectives of this study were i. to determine baseline sensitivity of $B$. cinerea to isofetamid and ii. to determine the effectiveness of isofetamid against grapevine gray mold under field conditions.

\section{Material and methods}

\section{Isolates}

Isolates of $B$. cinerea were collected from $V$. vinifera vineyards located between the Aconcagua valley and Los Angeles (Table 1). Pure isolates were cultured in potato dextrose

Table 1. Effectiveness of isofetamid against gray mold in apples and baseline sensitivity of Botrytis cinerea to isofetamid.

\begin{tabular}{|c|c|c|c|c|c|}
\hline \multirow[t]{2}{*}{ Isolates } & \multirow[t]{2}{*}{ Origin } & \multicolumn{2}{|c|}{$\begin{array}{l}\text { Median effective concentration, } \\
\qquad \mathrm{EC}_{50}{ }^{1} \mu \mathrm{g} \mathrm{mL}^{-1}\end{array}$} & \multicolumn{2}{|c|}{$\begin{array}{c}\text { Gray mold control }{ }^{2} \\
\%\end{array}$} \\
\hline & & Mycelium & Conidia & Mycelium & Conidia \\
\hline $\mathrm{bc} 1$ & Santiago & 5.3 & 0.6 & 100.0 & 100.0 \\
\hline bc4 & Los Andes & nd & 5.2 & 96.0 & 48.0 \\
\hline bc5 & Viluco & 10.0 & 5.3 & 76.0 & 94.6 \\
\hline bc6 & Nancagua & 2.5 & 4.5 & 65.5 & nd \\
\hline bc7 & Nancagua & 0.6 & 2.7 & 100.0 & nd \\
\hline bc 8 & Nancagua & 0.3 & nd & 100.0 & 37.5 \\
\hline bc9 & Requinoa & 0.8 & 10.0 & 100.0 & 100.0 \\
\hline bc10 & Nancagua & 1.4 & 3.7 & 100.0 & 100.0 \\
\hline bc11 & Casablanca & 3.0 & $>10$ & 61.0 & 93.4 \\
\hline bc12 & Los Angeles & 2.3 & 6.6 & 100.0 & 91.4 \\
\hline
\end{tabular}

${ }^{1} \mathrm{EC}_{50}$ was determined in vitro using MM and YBA media for mycelium and conidia, respectively. ${ }^{2}$ Performed in Granny Smith apples at label concentration of isofetamid $\left(0.4 \mu \mathrm{g} \mathrm{mL}{ }^{-1}\right)$. nd: not determined. 
agar acidified with $96 \% 0.5 \mathrm{~mL} \mathrm{~L}^{-1}$ lactic acid (APDA). Hyphal tips were transferred to fresh APDA plates and incubated at $22{ }^{\circ} \mathrm{C}$ for 4 days. Isolates were maintained in APDA at $20{ }^{\circ} \mathrm{C}$ until use.

\section{Fungicides}

In this study, the following fungicides were used: isofetamid (IKF-5411 40 SC, Sumitomo, Japan) and fenhexamid (Teldor $50 \mathrm{WP}$, Bayer Chile).

\section{Mycelium and conidia sensitivity}

The sensitivity of the mycelium of $B$. cinerea isolates to isofetamid was assayed using minimal agar media (MM) containing $10 \mathrm{~g}$ of glucose, 1.5 $\mathrm{g}$ of $\mathrm{K}_{2} \mathrm{HPO}_{4}, 2 \mathrm{~g}$ of $\mathrm{KH}_{2} \mathrm{PO}_{4}, 1 \mathrm{~g}$ of $\left(\mathrm{NH}_{4}\right)_{2} \mathrm{SO}_{4}$, $0.5 \mathrm{~g}$ of $\mathrm{MgSO}_{4} \cdot 7 \mathrm{H}_{2} \mathrm{O}, 2 \mathrm{~g}$ of yeast extract, and $12.5 \mathrm{~g}$ of agar (Hu et al., 2011). The plates were supplemented with $0.1,0.5,1.0,3.0,5.0$, and 10.0 $\mu \mathrm{L} \mathrm{L}^{-1}$ isofetamid. A mycelial plug (5 mm diameter) was placed at the center of the plates, with three replicates for each isofetamid concentration. The plates were incubated at $20^{\circ} \mathrm{C}$ for 4 days before determining the mycelium radial growth. An equal number of plates containing non-supplemented $\mathrm{MM}$ was the control. The conidial sensitivity to isofetamid was assayed using yeast malt extract agar (YBA) containing $10 \mathrm{~g}$ of yeast extract, 10 $\mathrm{g}$ of bacto peptone, $20 \mathrm{~g}$ of $\mathrm{Na}$ acetate and $15 \mathrm{~g}$ of agar (Hu et al., 2011). The plates were supplemented with $0.1,0.5,1.0,3.0,5.0$, and $10.0 \mu \mathrm{L}$ $\mathrm{L}^{-1}$ isofetamid. An aliquot $(100 \mu \mathrm{L})$ of conidial suspension $\left(1-2 \times 10^{6} B\right.$. cinerea conidia per $\left.\mathrm{mL}\right)$ of each isolate was plated and incubated for 18 $\mathrm{h}$ at $20^{\circ} \mathrm{C}$ before determining the proportion of germinated conidia. At least 100 conidia for each isolate and isofetamid concentration were examined by microscope. Conidia were considered to be germinated if the germ tube length was at least two-fold of the conidia diameter. An equal number of plates containing non-supplemented YBA was the control.

\section{Apple bioassay test}

To confirm in vitro results and to validate the label-recommended concentration, $0.4 \mu \mathrm{g} \mathrm{mL}^{-1}$ isofetamid was applied to Granny Smith apples under laboratory conditions (Latorre and Torres, 2012). Mature apples (13\% total soluble solids) were surface disinfected with $70 \%$ ethanol for 30 s. Three punctures were made aseptically to the apples using a hypodermic needle. An aliquot (30 $\mu \mathrm{L}$ ) of fungicide suspension was deposited over the punctures and left to dry for $2 \mathrm{~h}$ in a laminar flow chamber at $20^{\circ} \mathrm{C}$. The apples were then inoculated with $20 \mu \mathrm{L}$ of conidial suspension $\left(1-2 \times 10^{6} B\right.$. cinerea conidia per $\mathrm{mL}$ ) deposited over the punctures and the fungicide-treated tissue. Inoculated but non-treated punctures were the controls. All of the apples were incubated in humid chambers $(>80 \%$ relative humidity) in darkness for 7 days at room temperature $\left(20-22^{\circ} \mathrm{C}\right)$ before measuring the diameter of the necrotic lesion obtained. This experiment was repeated using mycelium plugs instead of conidia.

\section{Field studies}

Fungicide treatments. In this study, $40{\mathrm{~g} 100 \mathrm{~L}^{-1}}^{-1}$

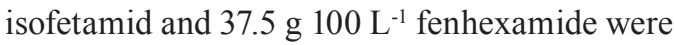
used. Fungicide treatments consisted of four spray applications conducted at critical growth stages of grape development: A. flowering, B. prebunch closure, C. veraison, and D. preharvest $(>15 \%$ total soluble solids) (Table 2). Products were sprayed with a backpack sprayer (Solo, Germany) with a 15-L capacity and directed to the clusters to run-off, using a mean equivalent to $1250 \mathrm{~L} \mathrm{ha}^{-1}$.

Vineyard locations. The experiments were conducted in commercial vineyards of Chardonnay, Flame Seedless, and Thompson Seedless grapes, located in Casablanca, Colchagua, and Nancagua, respectively. The Chardonnay grapes on a double wire vertical trellis system and the table grape cultivars were on a high trellis system with a 2-m high pergola. All of the vineyards had a history 
Table 2. Timing of applications of isofetamid and fenhexamid for the control of gray mold (Botrytis cinerea) at critical grapevine growth stages.

\begin{tabular}{|c|c|c|c|c|c|}
\hline \multirow{2}{*}{ Program } & \multirow{2}{*}{ Fungicides } & \multicolumn{4}{|c|}{ Critical growth stage periods } \\
\hline & & A & B & $\mathrm{C}$ & $\mathrm{D}$ \\
\hline \multirow{2}{*}{$\begin{array}{l}\text { Consecutive } \\
\text { applications }\end{array}$} & $\begin{array}{c}\text { Isofetamid } \\
\text { Fenhexamid }\end{array}$ & I & I & $\mathrm{F}$ & $\mathrm{F}$ \\
\hline & $\begin{array}{l}\text { Fenhexamid } \\
\text { Isofetamid }\end{array}$ & $\mathrm{F}$ & $\mathrm{F}$ & I & I \\
\hline \multirow{2}{*}{$\begin{array}{l}\text { Alternating } \\
\text { applications }\end{array}$} & $\begin{array}{l}\text { Isofetamid } \\
\text { Fenhexamid } \\
\text { Isofetamid } \\
\text { Fenhexamid }\end{array}$ & I & $\mathrm{F}$ & I & $\mathrm{F}$ \\
\hline & $\begin{array}{l}\text { Fenhexamid } \\
\text { Isofetamid } \\
\text { Fenhexamid } \\
\text { Isofetamid }\end{array}$ & $\mathrm{F}$ & I & $\mathrm{F}$ & I \\
\hline
\end{tabular}

${ }^{1} \mathrm{~A}$ : flowering, B: prebunch closure, C: veraison, D: preharvest,

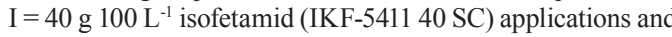

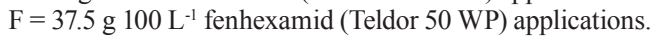

of gray mold presence and were managed using standard practice, with the exception that only the study fungicides were applied.

\section{Effectiveness of isofetamid at flowering stage}

The effectiveness of one spray application of isofetamid and fenhexamide at full bloom were evaluated by presence of $B$. cinerea on apparently healthy grape clusters. The level of $B$. cinerea was assessed in 100 apparently healthy flower samples for each of the four replicates performed $24 \mathrm{~h}$ after fungicide application. The flowers were distributed on Petri plates containing APDA plus $1.4 \mathrm{~mL} \mathrm{~L}^{-1}$ Igepal (Sigma-Aldrich, Saint Louis, MO, USA) as a colony growth restrictor. The plates were incubated at $20-22{ }^{\circ} \mathrm{C}$ for 7 days prior to determination of the total number of flowers exhibiting colonies of $B$. cinerea using a stereoscopic microscope.

\section{Effectiveness of isofetamid at harvest}

The effectiveness against gray mold at harvest of four isofetamid applications (at full bloom, prebunch closure, veraison, and preharvest) was compared with that of fenhexamid. Prevalence $(\%$ diseased clusters) and severity (number of diseased berries per cluster) was determined in 25 clusters per replicate performed 10 days after the last application.

\section{Residual fungicide effect on gray mold dispersal after harvest}

The objective was to estimate the residual effect of the last fungicide application in the vineyard on gray mold in each plastic pot. A 500-g berry sample per replicate was collected immediately after the last application. Berries were placed in 1-L plastic pots and transported to the laboratory where they were inoculated with one diseased berry. Diseased berries were obtained by inoculating surface-disinfected berries ( $30 \mathrm{~s}$ in $75 \%$ ethanol) with a mycelium plug of $B$. cinerea and incubated for 7 days at $20^{\circ} \mathrm{C}$ in humid chambers. All of the containers were incubated for 7 days at $20-22{ }^{\circ} \mathrm{C}$ before determining the proportion of rotted berries by weight.

\section{Effectiveness at harvest of consecutive applications of isofetamid at critical stages}

The effect of two consecutive applications of isofetamid alternated with two consecutive applications of fenhexamid was evaluated in Flame Seedless and Thompson Seedless table grapes, as indicated in Table 2.

\section{Effectiveness of alternating applications of isofetamid and fenhexamid}

The effect of alternating applications of isofetamid and fenhexamid was evaluated in Flame Seedless and Thompson Seedless table grapes, as indicated in Table 2 .

\section{Design and statistical analysis}

The effective mean concentration $\left(\mathrm{EC}_{50}\right)$ of isofetamid on mycelium growth and conidial germina- 
tion was estimated by lineal regression analysis between $\mathrm{x}=\log _{10}$ isofetamid concentration and $\mathrm{y}$ $=$ probit $\%$ inhibition. Apple bioassay treatments were arranged as a complete block design with four replicates, each consisting of one apple. Field treatments, including untreated controls, were distributed according to a complete block design with four replicates of four plants in table grapes and six plants in wine grapes. The results were analyzed for variance, and mean values were separated according to Duncan-Waller's multiple comparison k-ratio t test $(\mathrm{P} \leq 0.05)$.

\section{Results}

\section{Mycelium and conidia sensitivity}

In this study, the $\mathrm{EC}_{50}$ of mycelium growth inhibition of $B$. cinerea isolates varied between 0.3 and $10.0 \mu \mathrm{g} \mathrm{mL}^{-1}$ isofetamid and the $\mathrm{EC}_{50}$ of conidia germination inhibition varied between 0.6 and $10.0 \mu \mathrm{g} \mathrm{mL}^{-1}$ isofetamid (Table 1).

\section{Apple bioassay test}

In this study, the effectiveness of isofetamid against gray mold in apples varied between 61.0 and $100.0 \%$ of that of the control when the apples were inoculated with mycelium. Gray mold control varied between 37.5 and $100.0 \%$ when the apples were inoculated with conidia of $B$. cinerea (Table 1).

\section{Effectiveness of isofetamid at flowering stage}

Symptoms of gray mold were not observed at flowering under field conditions; however, colonies of $B$. cinerea were obtained after incubation for 4 to 7 days at $20^{\circ} \mathrm{C}$ in water agar.

Independent of the grape cultivar, flowering applications of isofetamid and fenhexamid had a significant $(\mathrm{P} \leq 0.01)$ effect in reducing the proportion of grape flowers exhibiting $B$. cinerea colonies. The fungicide treatments were similarly effective $(\mathrm{P}=0.05)$, reducing colonies of $B$. cinerea in flower samples (Table 3). B. cinerea colonies were gray and cottony with dark conidiosphores ending in bright white clusters of conidia, as viewed under a stereoscopic microscope (Figure 1).

\section{Effectiveness of isofetamid at harvest}

Gray mold developed on non-treated control fruit. The mold was characterized by the presence of soft decayed berries that started at the pedicel/berry interface. Abundant gray masses of conidial sporulation eventually formed nests of rotted berries.

In Chardonnay grapes, very low prevalence ( $4 \%$ of the bunches) and severity (mean 0.16 diseased berries per cluster) rates were observed, although the differences were not statistically significant between the fungicide treatments (Table 3). In non-treated controls, the prevalence was 20 and $26 \%$ in Flame Seedless and Thompson Seedless grapes, respectively. Mean disease severity was estimated to be 3.6 and 7.7 diseased berries per 25 clusters in Flame Seedless and Thompson Seedless grapes, respectively. In Flame Seedless grapes, a significant difference $(\mathrm{P}=0.05)$ in prevalence and severity rates between treated and non-treated controls was observed. However, in Thompson Seedless grapes, only the difference in prevalence between the treated and control groups was significant $(\mathrm{P}=0.05)$ (Table 3 ).

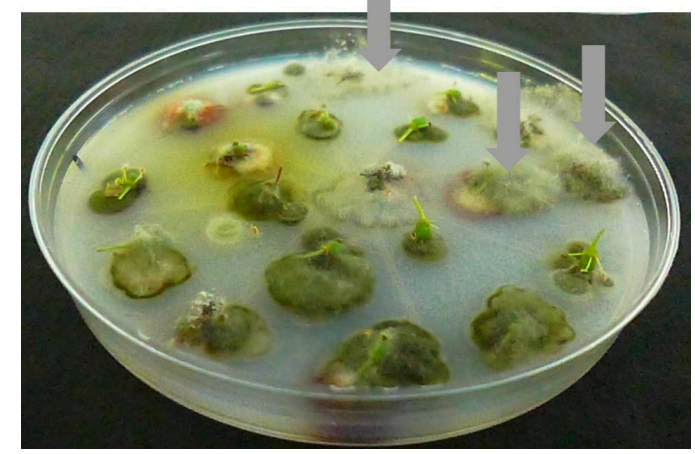

Figure 1. Colonies of Botrytis cinerea (arrows) from apparently healthy flowers of grapevines cultured in APDA. 
Table 3. Effectiveness of isofetamid and fenhexamid on Botrytis cinerea at flowering and control of grapevine gray mold at harvest and postharvest.

\begin{tabular}{|c|c|c|c|c|}
\hline \multirow{3}{*}{ Treatments $^{1}$} & \multirow{3}{*}{$\begin{array}{l}\text { B. cinerea }{ }^{2} \text { at } \\
\text { flowering, } \%\end{array}$} & \multicolumn{3}{|c|}{ Gray mold } \\
\hline & & \multicolumn{2}{|c|}{ At harvest ${ }^{3}$} & \multirow{2}{*}{$\begin{array}{c}\text { Postharvest }{ }^{4} \\
\text { Prevalence, \% }\end{array}$} \\
\hline & & Prevalence, $\%$ & Severity, no. & \\
\hline \multicolumn{5}{|c|}{ Wine grape cv. Chardonnay } \\
\hline Isofetamid & $7.5 \mathrm{a}^{5}$ & $3.0^{\mathrm{ns}}$ & $0.52^{\mathrm{ns}}$ & $2.8 \mathrm{a}^{5}$ \\
\hline Fenhexamide & $4.0 \mathrm{a}$ & 1.0 & 0.12 & $0.9 \mathrm{a}$ \\
\hline Control & $31.0 \mathrm{~b}$ & 4.0 & 0.16 & $9.2 \mathrm{~b}$ \\
\hline \multicolumn{5}{|c|}{ Table grape cv. Flame Seedless } \\
\hline Isofetamid & $9.8 \mathrm{a}$ & $5.0 \mathrm{a}$ & $0.60 \mathrm{a}$ & $6.0 \mathrm{ab}$ \\
\hline Fenhexamide & $7.3 \mathrm{a}$ & $3.0 \mathrm{a}$ & $0.28 \mathrm{a}$ & $5.1 \mathrm{a}$ \\
\hline Control & $21.8 \mathrm{~b}$ & $20.0 \mathrm{~b}$ & $3.60 \mathrm{~b}$ & $11.1 \mathrm{~b}$ \\
\hline \multicolumn{5}{|c|}{ Table grape cv. Thompson Seedless } \\
\hline Isofetamid & $4.0 \mathrm{a}$ & $10.0 \mathrm{a}$ & $6.4^{\mathrm{ns}}$ & $7.6 \mathrm{a}$ \\
\hline Fenhexamide & $6.0 \mathrm{a}$ & $8.0 \mathrm{a}$ & 3.4 & $6.6 \mathrm{a}$ \\
\hline Control & $24.0 \mathrm{~b}$ & $26.0 \mathrm{~b}$ & 7.7 & $14.3 \mathrm{~b}$ \\
\hline
\end{tabular}

'Isofetamid (IKF-5411 $40 \mathrm{SC}$, Sumitomo, Japan) applied at $40.0 \mathrm{~g} 100 \mathrm{~L}^{-1}$ and fenhexamide (Teldor 50 WP, Bayer Chile, Chile) applied at $37.5 \mathrm{~g} 100 \mathrm{~L}^{-1}$.

${ }^{2}$ Mean presence of $B$. cinerea in 100 apparently healthy flower samples incubated at $20-22{ }^{\circ} \mathrm{C}$ for 7 days.

${ }^{3}$ Prevalence estimated in 25 clusters per each of four replicates. Severity was estimated as the mean number of diseased berries in 25 clusters per replicate.

${ }^{4}$ Prevalence estimated in a humid chamber (with 1-L capacity) containing approximately $500 \mathrm{~g}$ of berries, collected $24 \mathrm{~h}$ after the last application and incubated for 7 days at $20^{\circ} \mathrm{C}$ after being inoculated in the laboratory.

${ }^{5}$ For each grape cultivar, mean values with the same letter are not significantly different according to Duncan-Waller $k$ ratio $t$ test $(\mathrm{P}=0.05)$.

$\mathrm{ns}=$ not significant.

\section{Residual fungicide effect on gray mold dispersal after harvest}

Soft decayed berries and white mycelium formed nests of rotted grapes around the inoculation site in non-treated controls. Gray rot prevalence was 9.2, 11.1, and $14.3 \%$ in Chardonnay, Flame Seedless, and Thompson Seedless grapes, respectively (Table 3). Regardless of the grape cultivar, a significant difference $(\mathrm{P}=0.05)$ in prevalence was observed between non-treated controls and cultivars treated with isofetamid or fenhexamid, showing a statistically similar degree of control between these fungicides (Table 3).

\section{Effectiveness of consecutive applications of isofetamid at critical stages}

Non-treated controls developed gray mold with a mean prevalence of 20 and 26\% in Flame Seedless and Thompson Seedless grapes, respectively. Mean disease severity was estimated to be 3.6 and 7.7 diseased berries per cluster in Flame Seedless and Thompson Seedless grapes, respectively. A significant difference $(\mathrm{P}=0.05)$ in prevalence and severity rates between treated and non-treated controls was observed in Flame Seedless grapes, but only the difference in prevalence was significant $(\mathrm{P}=0.05)$ in Thompson Seedless grapes. Regard- 
less of the cultivars, two consecutive applications of isofetamid and fenhexamid provided a similar degree of control (Table 4).

\section{Effectiveness of alternated applications of isofetamid and fenhexamid}

Non-treated controls developed gray mold at a mean prevalence of 20 and 26\% in Flame Seedless and Thompson Seedless grapes, respectively. Mean disease severity was estimated to be 3.6 and 7.7 diseased berries per 25 clusters in Flame Seedless and Thompson Seedless grapes, respectively. A significant difference $(\mathrm{P}=0.05)$ in prevalence and severity rates between treated and non-treated control was observed in Flame Seedless and Thompson Seedless grapes. Regardless of the cultivars, alternating applications of isofetamid and fenhexamid provided a similar degree of control (Table 5).

\section{Discussion}

This is the first study to report baseline sensitivities of $B$. cinerea to isofetamid in Chile. In this study, mycelium was less sensitive than conidia for isolate bcl, obtained from grapevines with no history of use of isofetamid or other SDHI fungicides. However, for isolates with a previous history of SDHI fungicide exposure, conidia were less sensitive than mycelium. These findings are in contrast with previous reports that mycelium and conidia are equally sensitive (Myresiotis et al., 2008) or that mycelium is less sensitive than conidia (Zhang et al., 2007) to boscalid, a fungicide with the same mode of action as isofetamid. Although B. cinerea isolates were not previously exposed to isofetamid, the in vitro $\mathrm{EC}_{50}$ for mycelium and conidia varied substantially between the isolates. These results may be attributed to the presence of cross-resistance in isolates that were previously exposed to boscalid. Nevertheless, in apples treated with either mycelium or conidia suspension, gray mold development was considerably arrested using the label-recommended concentration of isofetamid. Additional research is needed to investigate cross-resistance between boscalid and isofetamid.

Under the experimental conditions of this study, isofetamid, a new SDHI fungicide (FRAC, 2013) was equally effective as fenhexamid, which is

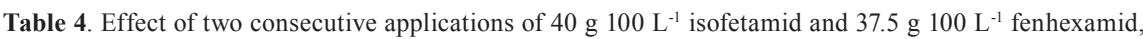
applied at critical growth stages of grapevine for gray mold (Botrytis cinerea) control.

\begin{tabular}{|c|c|c|c|c|c|c|c|}
\hline \multirow[b]{2}{*}{ Grape cultivars } & \multirow[b]{2}{*}{ Fungicides $^{1}$} & \multicolumn{4}{|c|}{ Critical growth stage periods ${ }^{1}$} & \multirow{2}{*}{$\begin{array}{c}\text { Prevalence }^{2}, \\
\%\end{array}$} & \multirow{2}{*}{$\begin{array}{c}\text { Severity }^{2} \\
\text { no. }\end{array}$} \\
\hline & & A & B & $\mathrm{C}$ & D & & \\
\hline \multirow{3}{*}{ Flame Seedless } & $\begin{array}{c}\text { Isofetamid (I) } \\
\text { Fenhexamid (F) }\end{array}$ & I & I & $\mathrm{F}$ & $\mathrm{F}$ & $4 \mathrm{a}^{3}$ & $0.12 \mathrm{a}^{3}$ \\
\hline & $\begin{array}{c}\text { Fenhexamid }(\mathrm{F}) \\
\text { Isofetamid (I) }\end{array}$ & $\mathrm{F}$ & $\mathrm{F}$ & I & I & $7 \mathrm{a}$ & $0.64 \mathrm{a}$ \\
\hline & Untreated & - & - & - & - & $20 \mathrm{~b}$ & $3.60 \mathrm{~b}$ \\
\hline \multirow{3}{*}{$\begin{array}{l}\text { Thompson } \\
\text { Seedless }\end{array}$} & $\begin{array}{c}\text { Isofetamid (I) } \\
\text { Fenhexamid (F) }\end{array}$ & I & $\mathrm{I}$ & $\mathrm{F}$ & $\mathrm{F}$ & $7 \mathrm{a}$ & $4.32^{\mathrm{ns}}$ \\
\hline & $\begin{array}{c}\text { Fenhexamid (F) } \\
\text { Isofetamid (I) }\end{array}$ & $\mathrm{F}$ & $\mathrm{F}$ & I & $\mathrm{I}$ & $7 \mathrm{a}$ & 1.32 \\
\hline & Untreated & - & - & - & - & $26 \mathrm{~b}$ & 7.68 \\
\hline
\end{tabular}

A: flowering, B: prebunch closure, C: veraison, D: preharvest.

${ }^{1} \mathrm{I}=40 \mathrm{~g} 100 \mathrm{~L}^{-1}$ isofetamid (IKF-5411 $40 \mathrm{SC}$ ) applications and $\mathrm{F}=37.5 \mathrm{~g} 100 \mathrm{~L}^{-1}$ fenhexamid (Teldor 50 WP) applications.

${ }^{2}$ Prevalence was estimated in 25 clusters for each of four replicates. Severity was estimated as the mean number of diseased berries in 25 clusters per replicate.

${ }^{3}$ For each grape cultivar, mean values with the same letter are not significantly different according to Duncan-Waller k ratio t test $(\mathrm{P}=0.05)$. ns $=$ not significant. 
Table 5. Effectiveness of alternating applications of isofetamid and fenhexamid for gray mold (Botrytis cinerea) control.

\begin{tabular}{|c|c|c|c|c|c|}
\hline \multicolumn{4}{|c|}{ Fungicide treatments at critical growth stages ${ }^{1}$} & \multicolumn{2}{|c|}{ Gray mold } \\
\hline A & $\mathrm{B}$ & $\mathrm{C}$ & $\mathrm{D}$ & Prevalence ${ }^{2}, \%$ & Severity $^{3}$, no. \\
\hline \multicolumn{6}{|c|}{ Flame Seedless } \\
\hline Isofetamid & Fenhexamide & Isofetamid & Fenhexamide & $7 \mathrm{a}$ & $0.32 \mathrm{a}$ \\
\hline Fenhexamide & Isofetamid & Fenhexamide & Isofetamid & $4 \mathrm{a}$ & $0.08 \mathrm{a}$ \\
\hline Untreated & Untreated & Untreated & Untreated & $20 \mathrm{~b}$ & $3.56 \mathrm{~b}$ \\
\hline \multicolumn{6}{|c|}{ Thompson Seedless } \\
\hline Isofetamid & Fenhexamide & Isofetamid & Fenhexamide & $6 \mathrm{a}$ & $3.32 \mathrm{ab}$ \\
\hline Fenhexamide & Isofetamid & Fenhexamide & Isofetamid & $7 \mathrm{a}$ & $1.00 \mathrm{a}$ \\
\hline Untreated & Untreated & Untreated & Untreated & $26 \mathrm{~b}$ & $7.68 \mathrm{~b}$ \\
\hline
\end{tabular}

A: flowering, B: prebunch closure, C: veraison, D: preharvest.

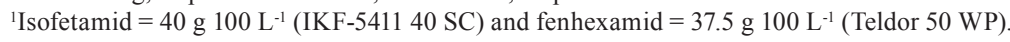

${ }^{2}$ Prevalence was estimated in 25 clusters for each of the four replicates. Severity was estimated as the mean number of diseased berries in 25 clusters per replicate.

${ }^{3}$ For each grape cultivar, mean values with the same letter are not significantly different according to DuncanWaller $\mathrm{k}$ ratio t test $(\mathrm{P}=0.05)$.

an ergosterol biosynthesis inhibitor widely used to control grape mold (Debieu et al., 2001). Both fungicides prevented gray mold development on grapevines by reducing $B$. cinerea at flowering and arresting gray mold infection at harvest time. As previously suggested for grapes and other fruits (Errampalli and Crnko, 2004; Frank et al., 2005; Sallato et al., 2007; Sholberg et al., 2003; Xiao, et al., 2009), residues of isofetamid and fenhexamid, resulting from field application at harvest, provided protection against the dissemination of gray mold in packaged grapes during storage. However, additional research, including fungicide residue analysis, is required to establish recommendations of preharvest isofetamid application to control gray mold during grape storage.

Isofetamid and fenhexamid were compared in two different geographical locations in the Nancagua Valley of Chile, where a moderate to high (20 to $26 \%$ ) gray mold prevalence was observed in non-treated table grape controls. The low prevalence (4\%) of gray mold observed in non-treated Chardonnay grapes in the Casablanca Valley was likely due to heavy leaf removal performed near veraison. Leaf removal reduces bunch zone humidity and increases bunch exposure to sunlight radiation, which are factors known to decrease gray mold incidence (Broome et al., 1995; Latorre et al. 2002).

B. cinerea can survive on crop debris and other decaying or damaged plant tissues, producing conidia that can be disseminated in the vineyard by wind and rain (Bulit and Dubos, 1988). These conidia often infect grape clusters at flowering and between veraison and harvesting. Commonly, B. cinerea develops latent infections in flowers that provide inoculum to infect berries or are expressed in the bunches at harvest or during storage. Therefore, chemical control must include fungicide application at flowering to reduce latent infections and control infections of flowering debris (Bulit and Dubos, 1988; Holz et al., 1997; Latorre and Vásquez, 1996; McClellan and Hewitt, 1973). Based on our results, isofetamid was effective at reducing flower colonization by $B$. cinerea and decreased the risk of subsequent infections at harvest and/or postharvest.

Two consecutive applications of isofetamid before or after two consecutive fenhexamid applications or alternating applications of these fungicides were equally effective against gray mold. These results suggest that the fungicide schedule was irrelevant to the effectiveness of both fungicides against gray 
mold. Nevertheless, it is important to avoid consecutive applications of isofetamid and fenhexamid to reduce the risk of resistance development because these fungicides are single-site mode of action (FRAC, 2013). However, additional research is required to establish recommendations of preharvest application to control gray mold during storage.

In conclusion, the new SDHI fungicide isofetamid was equally effective as fenhexamid in field conditions. Therefore, isofetamid is an alternative chemical treatment against gray mold in grapevines in Chile. However, its legal use is restricted until this compound is registered in Chile and in other countries.

\section{Acknowledgments}

The authors of this work are very grateful to Dr. Melvin Grove from Bioscience for the financial support received to conduct this study.

\section{Resumen}

C.M. Piqueras, B.A. Latorre y R. Torres. 2014. Eficacia de isofetamid, un nuevo fungicida inhibidor de la succinato deshidrogenasa, en el control de moho gris de la vid. Cien. Inv. Agr. 41(3): 365-374. El moho gris (Botrytis cinerea) es una enfermedad importante de la vid (Vitis vinifera) en Chile. En los últimos años el control se ha basado en la utilización de fungicidas de modo de acción específico lo que conlleva a un alto riesgo de desarrollo de resistencia. Por lo tanto, se necesitan nuevas opciones químicas para lograr un control satisfactorio de moho gris. Isofetamida es un nuevo fungicida de sitio específico que actúa inhibiendo la respiración celular. Este fungicida se presenta como una nueva opción en el control químico contra el moho gris. El objetivo de este estudio fue determinar la efectividad de isofetamida en el control del moho gris de la vid en Chile. Las pruebas de campo se realizaron en tres viñedos comerciales donde isofetamida demostró tener alta eficacia, similar a fenhexamida, sobre el moho gris. Durante 2012 y 2013, 10 aislamientos se obtuvieron de diferentes viñedos comerciales en el centro de Chile. La concentración mediana efectiva de isofetamida varió entre 0,3 a $10,0 \mu \mathrm{g} \mathrm{mL}^{-1}$ y 0,6 a $>10 \mu \mathrm{g} \mathrm{mL}^{-1}$ para micelio y conidias respectivamente. La eficacia de isofetamida contra B. cinerea varió entre $61.0-100.0 \%$ y $37.5-100.0 \%$, en bioensayos de manzanas inoculadas con micelio y conidias respectivamente. Los resultados de este estudio demuestran que isofetamida es un fungicida altamente eficaz contra $B$. cinerea.

Palabras clave: Control químico, fenhexamid, fungicidas, isofetamid, SDHI, Vitis vinifera.

\section{References}

Avenot, H., and T. Michailides. 2010. Progress in understanding molecular mechanisms and evolution of resistance to succinate dehydrogenase inhibiting (SDHI) fungicides in phytopathogenic fungi. Crop Prot. 29: 643-651.

Broome, J.C., J.T. English, J.J. Marois, B.A. Latorre, and J.C. Avilés. 1995. Development of an infection model for Botrytis bunch rot of grapes based on wetness duration and temperature. Phytopathology 85: 97-102.

Bulit, J., and B. Dubos. 1988. Botrytis bunch rot and blight. Pages 13-15. In: R.C. Pearson and A.C. Goheen (eds.). Compendium of Grapes Diseases. The American Phytopathological Society. St. Paul, Mn.

Chatzidimopoulos, M., D. Papaevaggelou, and A. C. Pappas. 2013 Detection and characterization of fungicide resistant phenotypes of Botrytis 
cinerea in lettuce crops in Greece. Eur. J. Plant Pathol. 137:363-376.

Debieu, D., J. Bach, M. Hugon, C. Malosse, and P. Leroux. 2001. The hydroxyanilide fenhexamid, a new sterol biosynthesis inhibitor fungicide efficient against the plant pathogenic fungus Botryotinia fuckeliana (Botrytis cinerea). Pest Manag. Sci. 57: 1060-1067.

FRAC. 2013. FRAC Code List (C* 2013: Fungicides sorted by mode of action (including FRAC Code numbering). Fungicide Resistance Action Committee (FRAC). Brussels, Belgium. Available online at: http://www.frac.info (Web accessed November 2013).

Holz, G., S. Coertze, and E.J. Basson. 1997. Latent infection of Botrytis cinerea in grape pedicels leads to postharvest decay. Phytopathology (Abst.) 87:S43.

Hu, M.-J. Chao-Xi Luo, A. Grabke, and G. Schnabel. 2011. Selection of a suitable medium to determine sensitivity of Monilinia fructicola mycelium to SDHI fungicides. J. Phytopathol. 159:616-620.

Kim, Y.K., and C.L. Xiao. 2010. Resistance to pyraclostrobin and boscalid in populations of Botrytis cinerea from stored apples in Washington State. Plant Dis. 94:604-612.

Latorre, B.A., and G. Vásquez. 1996. Situación de Botrytis cinerea latente en uva de mesa en la zona central. Aconex (Chile) 52:16-21.

Latorre, B.A., and R. Torres. 2012. Prevalence of isolates of Botrytis cinerea resistant to multiple fungicides in Chilean vineyards. Crop Prot. 40: 49-52.

Latorre, B.A., C. Lillo, and M.E. Rioja. 2001. Effect of timing on the efficacy of fungicide treatments applied against Botrytis cinerea of grapevine. Cien. Inv. Agr. 28:61-66.

Latorre, B.A. 1986. Manejo de Botrtyis cinerea en uva de mesa. Revista Frutícola (Chile) 7: 75-88.

Latorre, B.A., I. Spadaro, and M.E. Rioja. 2002. Occurrence of resistant strains of Botrytis cinerea to anylinopirimidine fungicides in table grapes in Chile. Crop Prot. 21: 957-961.

Leroux, P. 2007. Chemical control of Botrytis and its resistance to chemical fungicides. Pages 195-222. In: Y. Elad, B. Williamson, P.Tudzinski, and N. Delen (eds.). Botrytis: Biology, Pathology and Control. Springer Verlag, Dordrecht, The Netherlands.

McClellan, W.D., and W.B.Hewitt. 1973. Early Botrytis rot of grapes: Times of infection and latency of Botrytis cinerea Pers. in Vitis vinifera L. Phytopathology 63: 1151-1157.

Molitor, D., M. Rothmeier, M. Behr, S. Fischer, L. Hoffmann, and D. Evers. 2011. Crop cultural and chemical methods to control grey mould on grapes. Vitis 50: 81-87.

Myresiotis, C. K., G.A. Bardas, and G.S. Karaoglanidis. 2008. Baseline sensitivity of Botrytis cinerea to pyraclostrobin and boscalid and control of anilinopyrimidine- and benzimidazoleresistant strains by these fungicides. Plant Dis. 92:14271431.

Sallato, B. V., R. Torres, J. P. Zoffoli, and B. A. Latorre. 2007. Effect of boscalid on postharvest decay of strawberry caused by Botrytis cinerea and Rhizopus stolonifer. Span. J. Agric. Res. 5: 67-78.

Vail, M. E., and J.J. Marois. 1991: Grape cluster architecture and the susceptibility of berries to Botrytis cinerea. Phytopathology 81: 188-191.

Yin, Y.N., Y.K. Kim, and C.L. Xiao. 2011. Molecular characterization of boscalid resistance in field isolates of Botrytis cinerea from apple. Phytopathology 101:986-995.

Zhang, C.Q., S.K. Yuan, H. Y. Sun, Z.Q. Qi, M.G. Zhouand, and G.N. Zhu. 2007. Sensitivity of Botrytis cinerea from vegetable greenhouses to boscalid. Plant Pathol. 56: 646-653.

Zoffoli, J.P., and B.A. Latorre. 2011. Table grapes. Pages 179-212. In: E. M. Yahia (ed.). Postharvest Biology and Technology of Tropical and Sub-Fruits. Woodhead Publishing Limited. Oxford, UK. 